\title{
Improving Learning Outcomes Reading Comprehension Using SQ3R Model
}

\author{
Vini Wela Septiana ${ }^{1)}$, Ambiyar ${ }^{2 *}$, Ishak Aziz ${ }^{3)}$
}

1) Program Studi Doktor Ilmu Pendidikan Pascasarjana Universitas Negeri Padang

2) Universitas Negeri Padang

*Coresponding Author

Email : viniwela86@gmail.com

\begin{abstract}
In this research, the writer used an action research. For collecting the data, the writer used test and observation. The data sources were the 4th grade SD Negeri 07 Padang which consists of 17 students and a Teacher as the observer. Cycle I consists of planning, action, observation and reflection. Cycle II added by the revision of cycle I. Based on the results of the research, The success in this research has increased from cycle to cycle. Where the results of the lesson plan of cycle I with an average of $82 \%$ (good), in the second cycle with an average value of $85 \%$ (very good), from the teacher aspect in the first cycle with an average value of $85 \%$ (very good), in the second cycle with the average value of 93\% (very good), while in the aspect of the first cycle students with an average value of $63 \%$ (enough), in the second cycle with an average value of $93 \%$ (very good). The learning outcomes in this cycle indicate that the average value is $65 \%$ (enough), increasing in the second cycle with an average value of $82 \%$ (Good). Thus, the hypothesis in this research is acceptable. It means, there is a significant improving in using SQ3R to increase the students' reading comprehension in SD Negeri 07 Padang. The study of conducting action research is invaluable and inspiring experience that gives the researcher new knowledge. It is hoped that action research can be implemented by other researchers to achieve a better teaching and learning process.
\end{abstract}

Keywords: classroom action research, SQ3R model, students' reading comprehension.

\section{INTRODUCTION}

Language education is a means of learning correct communication in interacting in everyday life. Teaching Indonesian consists of several aspects of language and literary skills, namely aspects of reading, writing, listening and speaking skills. These four skills are interrelated with each other both in daily life and in the learning process. For this reason, Indonesian language learning must be further improved both in terms of learning strategies, facilities and supports.

Reading is crucial skill since it is assumed to be the central means to get new information. It is becomes basic skill for academic purpose to increase his or her knowledge. This idea is supported by the fact that reading has become part of our daily activities (Grabe \& Stoller, 2001:12). 
Reading gives a great influence for our life because we are able to find knowledges that are written in many books. But it is very complicated or complex, because it is an activity carried out under the cooperation of several skills, as observing, understanding, and thinking that can support these skills, and it also depends on the language skills and the level of reasoning.

Reading process is a great source of language learning because language can be acquired from reading as opposed to studied directly (Pollard, 2008:44). The reading problems are related to determine the main idea. This case can make the students less confident, and surrender before catching the main idea. It means that one of the students' difficulties in reading text is in determining the main idea in a paragraph of the text.

Reading only is not enough because the precious one is reading with comprehending the text. Tankersley states, comprehension is the center of reading. She also says comprehension is the heart of reading process and we bring our life experiences to the act of reading. When an effective reader reads for comprehension and understanding, it is actively engaged and thoughtful process. It means that reading is an interactive process between readers and the text. The readers automatically interact with the text to get main information in the text. It can make the readers comprehend the text easier if they serious in the reading process.

The problems about reading were also found by the researcher when he observed at the 4th grade SD Negeri 07 Padang. The problems showed that the seventh grade students have difficulties in reading comprehension such as: finding the main ideas, pointing general and specific information, and comprehending words' meaning. Another problem was also caused by the application of teaching technique which was still traditional it's still used monotone technique. in reading comprehension such as learners' lack of vocabulary and motivation because they feel hard to comprehend the texts that are given by the teacher. As the result, they get difficulties when answering questions following reading texts, they do not understand what the text tells about. Other indicators are shown in the classroom atmosphere. During the teaching learning process, the students are not enthusiastic and interested in joining teaching activities.

Based on the fact, the classroom teacher and the writer would like to improve their proficiency in reading comprehension by using SQ3R model. According to Huber, SQ3R is suitable technique to increase our reading comprehension ; therefore, can help us to make sense of unfamiliar information text, this technique focused on search for new information and remember what we read. This strategy actually allows the students to become more actives participants in reading. SQ3R consists of five steps namely Surveying, Questioning, Reading, Reciting, and Reviewing. SQ3R is a comprehension. strategy that helps students think about the text they are reading while they're reading SQ3R is a comprehension. strategy that helps students think about the text they are reading while they're reading. Often categorized as a study strategy, SQ3R helps students "get it" the first time they read a text by teaching students how to read and think like an effective reader.. Often categorized as a study strategy, SQ3R helps students "get it" the first time they read a text by teaching students how to read and think like an effective reader. However, in order to carry out this method successfully, the students should have the ability for understanding the text structure and taking the main idea of the text. Those steps are important and related each other to form an effective reading strategy, in relation this, the study essentially conducted to know the degree of improvement the $4^{\text {th }}$ grade 
students of SD Negeri 07 Padang in reading Comprehension through SQ3R. Besides, this solution and this strategy is hoped to minimize the students' error in reading comprehension.

Based on the description above, the researcher would like to do a research to determine whether or not SQ3R can improve students' reading comprehension of SD Negeri 07 Padang; thus, the researcher use this strategy is hoped to make the students more understand about how to be a good reader; consequently, the important of reading comprehension in learning. SQ3R is a method that the writer believes can help the students to overcome their reading problems in terms of the difficulty in comprehending the material, unmotivated in reading material, and forgetting the material they had just read easily.

Based on the problems above, the researcher interested to conduct a research with the title: "Improving learning outcomes reading comprehension using SQ3R model in SD Negeri 07 Padang",

\section{RESEARCH METHODS}

\section{Type Of Research}

The research is a classroom action research design. Action research is a combination of both action and research. On the other hand, classroom action research is one of research that usually done in part cultural class which had a problem in learning, where this research could give solution for the problem. There are various definitions of action research stated by some experts. Cohen et al. (2000) states that classroom action research is a powerful tool for change and improvement at the local level.

\section{Data Collection techniques and Research Instruments Data Collection Techniques}

The data collection technique is used by researchers in conducting a research, Widodo, (2018). Data Collection techniques in this research is a Questionnaire used to Determine the response of students towards learning through peer tutoring and the level of Self Confidence of the students .In addition to the Questionnaire, data collection techniques in this study also use the Test in the form of a description of the material Functions. The test is used to determine the level of mathematical communication skills of students. The test is given twice, before the material given to the students, to determine the ability of beginning students are then given a pretest and after all the material presented given the post-test.

\section{Research Instruments}

The instruments used in this research were questionnaires and Tests. Questionnaire

According to Sudaryono questionnaire or a questionnaire is a technique or way of collecting data is done indirectly ( researchers did not directly ask-answered by respondents). The questionnaire in this study is intended to measure the Self Confidence or the confidence of students. questions in the questionnaire form of the question of the positive and negative questions. Answers on each item questions using the Likert scale. Likert scale contains four alternative answer options namely Strongly Agree (SS), Agree (S), Disagree (TS), and Strongly Disagree (STS). 


\section{Test}

The data in the form of quantitative method are got from the test. The test is in the form of reading comprehension. In this research, the researcher does pre-test in the beginning of the teaching learning process and post-test done in the end of each cycle

\section{The Technique of Colleting Data}

In this classroom action research, the data which are collected by the researcher are using qualitative and quantitative method. The data in the form of qualitative method are got from the observation done by the teacher during the teaching learning process about the whole activities and the students' behavior. The observation is done by making notes about the activities during the teaching learning process. Besides that, the observation is also supported by taking a photograph during the teaching learning process and the interviews is done after the teaching learning process.

\section{Technique of Analyzing of the Data}

In analyzing the qualitative data, the researcher analyzed the result of observation done during the process by using constant comparative method as suggested by Glasser and Srratus. The data analysis process of constant comparative method includes four steps (1967: 105-113), as follows:

1. Comparing incidents applicable to each categories. It is started by coding each incident in the data into as many categories of analysis as possible. Some categories will be generated, some from the language and data of the research situation.

2. Integrating categories and their properties. The constant comparative units change from comparison of incident with incident to comparison of incidents with properties of the category that resulted from initial comparison of incidents. Diverse properties will starts to become integrated.

3. Delimiting theory. Here the theory is delimited and generalized more as continued to make constant comparisons against it. The number of categories will be reduced. Then, the researcher only needs to code enough to fulfill the properties of the categories. The categories were evaluated and the theory are emergent by moving on to new comparison groups.

4. Writing the theory. The researcher possesses coded data, a series of memos, and a theory. The discussion in this memo provides the content behind the categories which become the major themes of the theory. The quantitative data is analyzed by using descriptive statistic. It is used to analyze data from the result of the teaching learning process. It is done to compare the students' speaking skill before and after the action or the result of pre-test and post-test.

\section{RESULTS AND DISCUSSION}

The research was carried out in $4^{\text {th }}$ grade of SD Negeri 07 Padang. The implementation of the action was carried out in two cycles with a span of two weeks. In the implementation of the action, the researcher acts as a teacher while the fourth grade teacher and colleagues act as 
observers. The implementation of the action is divided into two cycles, where the data for each cycle is presented separately from the other cycles in order to see the similarities, differences, changes or developments of the cycle path.

The results of the research in each cycle are described as follows.

\section{a. Cycle I Meeting I}

1)Planning: Planning of learning activities is outlined in a learning implementation plan (lesson plan). The lesson plan is an operational form of learning activities carried out in the text. (lesson plan) provides pictures of the forms of activities that will be implemented.

2)Implementation: Learning activities are carried out with a period of twice a week for one month, carried out according to the learning implementation plan that has been prepared. Learning activities are carried out in two cycles. Where cycle I is divided into two meetings, and there is cycle II divided into two meetings as well. With the steps of the SQ3R learning model: a. (Students conduct a survey of the reading text), b. (Students ask questions (question), c. (Students read the reading text as a whole (read), d. (Students discuss with their classmates and answer questions (recite) about new information contained in the reading text), e. (Students repeat (review) the results of their group discussions in the form of discussion reports).

3)Observation: Learning observations are carried out continuously starting from the initial action to cycles I and II. The final action of this observation is reflected for planning at the next meeting.

4)Reflection: Learning outcomes are assessed from three aspects, namely the cognitive, affective and psychomotor domains. Assessment of cognitive aspects is assessed on individual activities and tests carried out at the end of learning activities. This result is a determinant of whether the learning activities carried out are successful or not.

\section{Discussion}

The results of the research are:

1. The learning implementation plan using the SQ3R model is divided into three learning stages, namely initial, core and final activities. In the initial activity, activities were carried out to activate the knowledge of students. At the core stage, learning is carried out using the steps of the SQ3R model, and the final stage is carrying out learning conclusions and giving evaluations.

2. The form of implementation of Indonesian language learning is adjusted to the steps of using the SQ3R model, namely students conduct a survey of the reading text. Everyone asks a question (question). Everyone reads the text in its entirety (read). Everyone answers the questions that have been asked (recite). Everyone repeats the results of their discussion (review). In the final activity, follow-up and evaluation are carried out according to the material that has been discussed in the lesson.

3. The results showed that there was an increase in learning outcomes. Judging from the observations of the lesson plan in the first cycle of the first meeting it was $82 \%$ (Good), the second cycle of the second meeting was $87 \%$ (Very Good). The results of observations from the teacher aspect of the first cycle of the first meeting were $87 \%$ (Very Good), the teacher aspect of the first cycle of the second meeting was $91 \%$ (Very Good), the teacher aspect of the second cycle of the first meeting was $91 \%$ (Very Good), the teacher aspect of the second cycle of the second meeting was $95 \%$ (SB). Meanwhile, from the aspect of the students of the first cycle of the first meeting, 66\% (Enough), the aspect of the students of the first cycle of the second meeting was $78 \%$ (Good), the aspect of the students of the second cycle of the 
first meeting was 91\% (Very Good), the student aspect of the second cycle of the meeting II is $96 \%$ (Very Good).

4. The results of students in learning Indonesian using the SQ3R model in $4^{\text {th }}$ grade of SD Negeri 23 Lolong, Padang City have increased. The results of research that have been carried out in cycle I and cycle II obtained an increase in success in the cognitive, affective, and psychomotor aspects of students. In the first cycle the average cognitive aspect was $65 \%$ (Enough) in the second cycle it increased to $84.58 \%$ and the affective average in the first cycle was $75 \%$ (Good) and in the second cycle it increased to $80 \%$ (Good) and the average the average psychomotor aspect in the first cycle is $74 \%$ (Good) and in the second cycle it increases to $81 \%$ (Good), seen the average of these three aspects in the first cycle is $72 \%$ (Good), and in the second cycle it increases to $81 \%$ (Good).

\section{CONCLUSION}

Based on the analysis and discussion of the results of testing the hypothesis that the researcher has done asked some important conclusions which is the core of the results research this is as follows:

The present classroom action study dealt with improving the reading comprehension of the $4^{\text {th }}$ grade students of SD Negeri 07 Padang through SQ3R. The selection of the seventh grade students of the $4^{\text {th }}$ grade students of SD Negeri 07 Padang was preceded by conducting a preliminary study. Based on the study, it was found that the the $4^{\text {th }}$ grade students of SD Negeri 07 Padang have problem in reading comprehension, such as they were difficult to understand general and specific information, textual meaning, and textual reference. The effectiveness of this teaching strategy could be clearly seen by comparing the score of initial reflection to post test in cycle I and II. Furthermore, questionnaire that researcher had given to the subject under study showed the students' positive changing behavior. The interest of the subjects under study to learn English especially reading comprehension was increased by using SQ3R. It was supported by requiring data from the questionnaire item to the subject under study. Finally, it can be concluded that the problems faced by the $4^{\text {th }}$ grade students of SD Negeri 07 Padang in reading comprehension could be solved through the implementation of SQ3R on teaching-learning process. The answer of research question is SQ3R could improve students' reading comprehension of the the $4^{\text {th }}$ grade students of SD Negeri 07 Padang.

\section{REFERENCES}

Ahmad Tamzeh, Metodologi Penelitian Praktis (Yogyakarta: Penerbit Teras, 2011).

Cohen, L., et. al. Research Methods in Education. (New York: Rutledge Falmer. 2001).

Grabe \& Stoller. (2001). Anxiety and Reading Comprehension Performance in English as a Foreign Language. Asian EFL Journal Volume 13 Issue 2, 279.

Huber, J. A. A Closer Look at SQ3R. Reading Improvement, 41(2), (2004) 108- 112. 
Volume 1, Number 3, December 2021, Page. 75 - 81

Email : editorijhess@gmail.com

Karen Tankersley, 2003.The Threads Of Reading : Strategies For Literacy Development ASCD.

Pollard'. L. Guide to teaching English. A book to help you through your first two years in teaching. (London. 2004).

Sudaryono, 'Aplikasi Analisis ( Path Analysis ) Berdasarkan Urutan Penempatan Variabel Dalam Penelitian', Pendidikan Dan Kebudayaan, 17.4 (2002), 394.

Widodo. Metodologi Penelitian Populer \& Populer/Praktis, 1st edn (Depok: Rajawali Pers, 2018). 